\title{
Repeating Marx: Introduction to the Special Issue "Karl Marx @ 200: Debating Capitalism \& Perspectives for the Future of Radical Theory"
}

\author{
Christian Fuchs* and Lara Monticelli** \\ *University of Westminster, London, UK, christian.fuchs@triple-c.at \\ **Independent researcher, monticelli.lara@gmail.com
}

\begin{abstract}
This introduction sets out the context of the special issue "Karl Marx @ 200: Debating Capitalism \& Perspectives for the Future of Radical Theory", which was published on the occasion of Marx's bicentenary on 5 May 2018. First, we give a brief overview of contemporary capitalism's development and its crises. Second, we argue that it is important to repeat Marx today. Third, we reflect on lessons learned from 200 years of struggles for alternatives to capitalism. Fourth, we give an overview of the contributions in this special issue. Taken together, the contributions in this special issue show that Marx's theory and politics remain key inspirations for understanding exploitation and domination in 21 st-century society and for struggles that aim to overcome these phenomena and establishing a just and fair society. We need to repeat Marx today.
\end{abstract}

Keywords: Karl Marx, capitalism, class, bicentenary, 200th anniversary, 5 May 2018, 1818

\section{Capitalism and Class 200 Years after Marx's Birth}

5 May 2018 marks the 200th birthday of Karl Marx. The tripleC special issue "Karl Marx @ 200: Debating Capitalism \& Perspectives for the Future of Radical Theory" takes this anniversary as the occasion for discussing the relevance of Marx's works and the Marxian critique of capitalism today. The special issue asks: How can Marx's theory help us understand capitalism today? What type of capitalism do we live in today, 200 years after Marx's birth? What kind of Marxian analysis, focus and praxis do we need for the analysis and critique of capitalism? Which elements of Marx's theory and the history of Marxian theory can we best draw from in order to advance radical theory, the analysis of capitalism, and struggles for alternatives to capitalism?

With works such as Capital, Grundrisse, Economic \& Philosophic Manuscripts, The German Ideology, The Communist Manifesto, Class Struggles in France, The 18th Brumaire of Louis Bonaparte, Contribution to Critique of Political Economy, The Civil War in France, Theories of Surplus-Value, and many others, Marx laid the foundations for the critique of capitalism's political economy. The approach he advanced operates with the help of categories such as the commodity, work, labour, exchangevalue, use-value, value, the labour theory of value, labour-time, abstract and concrete labour, money, capital, capitalism, wages, prices, profits, fetishism, surplusvalue, necessary labour, surplus labour, class, exploitation, alienation, accumulation, profit, ideology, absolute and relative surplus-value production, formal and real subsumption, co-operation, machinery, the means of production, the general intellect, the means of communication, the collective worker, the rate of surplus-value, the organic composition of capital, the rate of profit, the international division of labour, primitive accumulation, the antagonism of productive forces and relations of production, modes of production, capitalist crises, overaccumulation, the tendency of the profit rate to fall, the anarchy of the market, overproduction, underconsumption, prof- 
it-squeeze, devaluation, fictitious capital, rent, landed property, transportation, the world market, uneven geographical development, global capital, colonialism, imperialism, interest, credit, the historical tendency of capitalist accumulation, circulation, reproduction, consumption, distribution, merchant's capital, departments I \& II of social production, the state, species-being, Bonapartism, materialism, the dialectic, contradictions, class struggles, class consciousness, realm of necessity, realm of freedom, the commons, communism, socialism, etc.

Taken together, these categories form the foundations of a critical theory of capitalism and of its economic system, political system, cultural system, its technological paradigms, the human/nature relationship within capitalism, and aspects of subject/object and time/space in capitalism. Marx's approach is inherently critical, which means that it analyses capitalism's contradictions, its crisis tendencies, struggles and the foundation of alternatives to capitalism as the determinate negation of capitalism. The development of Marxian theory has resulted in numerous approaches, strands, interpretations, debates, and conflicts.

The rise of neoliberal capitalism in society, of postmodernism in culture and academia and of identity politics has, together with the collapse of the Soviet system, the degenerations brought about by various forms of Stalinism, and the neo-liberalisation of social democracy, resulted in a decline of Marxian-inspired theory and praxis during the past decades. Francis Fukuyama was therefore able to postulate in 1992 that the end of history had arrived and to claim that capitalism and liberal democracy would exist forever. Many academics in the social sciences and humanities have to a certain extent practiced 'Fukuyamaism' by forgetting about capitalism and the analysis of society's totality. They have instead focused on micro-analysis, postmodernism, the attack on 'grand narratives' and truth claims, and categories such as globalisation, individualisation, risk, networks, modernity, identity, etc. While Marx has increasingly become absent in theory and praxis, the class contradiction and inequalities have expanded so that he, paradoxically, in light of his absence, has become more needed than ever before.

25 years after Fukuyama's claims about the end of history, societies and sociology have changed. The notion of capitalism has in the light of capitalism's actual crisis made a return into the public and sociological vocabulary. A new world economic crisis emerged in 2008. In many parts of the world it turned into a political, social, austerity, ideological, and legitimacy crisis of capitalist society as well as into the rise of new nationalisms and authoritarian forms of capitalism (Fuchs 2018). Marx keeps on haunting capitalism in the 21st century. Talking about Marx means talking about class, capitalism, crisis and alternatives to capitalism. It is therefore evident that Marx will remain our contemporary as long as capitalism continues to exist.

Whereas in the 1990s and the first decade of the 2000s it was difficult to talk about Marx without immediately being confronted with the ten unreflected prejudices against Marx that Terry Eagleton (2011) identifies, to the extent that a discussion about Marx and the critique of capitalism could not even be started, today there is more willingness to listen to what Marxist theory has to say. In the age in which neoliberal capitalism is in deep political, economic and ideological crisis and tends to turn into new authoritarian capitalisms, it has not only become evident that the market and the commodity form are unable to solve human problems but also that the time has come to once again take Marx and socialism seriously.

Capitalism is not an economic system but a type of society that is based on the logic of accumulation of money, power, reputation, visibility and their asymmetric 
control. Capitalism is making and unmaking itself through crises and social struggles from above and below.

Economically, capitalism's contradictions are again and again unmaking social and economic stability. These contradictions result in socio-economic crises. Contradictions have resulted in the 2008 world economic crisis and the austerity crisis - crises that cause misery for so many people and capitalism's periphery countries such as Greece.

Spatially, capitalism is unmaking its own boundaries. It is making new milieus of accumulation and exploitation and new boundaries. Temporally, capitalism unmakes the pace of society. And it makes new standards of abstract time and abstract labour. We experience the ever-increasing acceleration of life.

Politically, capitalism makes and unmakes state power. The surveillance state has emerged. We experience a negative dialectic in which the neoliberal capitalist state turns against itself and increasingly produces the authoritarian capitalist state.

Ideologically, capitalism continuously makes and remakes political fetishisms. Political fetishism today constitutes the rise of new nationalisms, new racism and xenophobia. These phenomena can only be unmade by political movements that defetishise the nation.

Technologically, capitalism unmakes existing standards of productivity by making new technological paradigms. As a consequence, we have seen the rise of digital capitalism and phenomena such as social media, big data, digital labour and the Internet of Things.

At the level of the military, capitalism unmakes peace by making new forms of conflict, confrontation and imperialism.

At the level of culture, capitalism unmakes the boundaries between the universal and the particular, labour/leisure, work/play, the home/the workplace, production/consumption, the public/the private, unity/diversity, object/subject, collective/individual, nature/culture, love/hate. Under the logic of instrumental reason, capitalist liquefaction makes new contradictions in our everyday lives.

At the level of the subject, capitalism makes and unmakes our individual and collective identities and desires. Our subjectivities are becoming instrumentalised, controlled, and commodified. Emotional capitalism has emerged.

All of these processes of capitalist making and unmaking are intertwined. They constitute a multi-faceted and complex unity of diverse capitalisms. Capitalisms are crisis-prone and constitute multiple contradictions and conflicts.

To say capitalism '(un)makes' itself means that it is made and unmade by groups and classes' collective practices. The political point for a better future is that people make their own history: that they unmake inequalities, exploitation and domination.

The present introduction gives an overview of the contributions in this special issue (Section 2), discusses what we can learn from 200 years of social struggles for establishing alternatives to capitalism (Section 3), and provides a historical and political perspective on the events and writings on the occasion of Marx's centenary in May 1918.

\section{Repeating Marx}

Facing economic, political, ecological and ideological crises, we have to repeat Marx today. Repeating Marx does not mean mechanically applying Marx's thought to 21stcentury society. It also does not mean to treat his writings as scriptures, from which one repeats one and the same quotations over and over again. 
First, to repeat Marx today means to develop analyses and critiques of class and capitalism in the 21st century in a historical and dialectical manner. It means to study how capitalism, not just as economic formation but also as societal formation, is transforming and damaging human lives, society and nature. It means repeating Marx's categories - such as the commodity, labour, value, surplus-value class, exploitation, capital, domination, ideology, class struggles, means/relations/modes of production, means of communication, the general intellect, communism, etc. - in the 21st century. Marx was both a historical and a dialectical thinker. To repeat Marx in the 21st century therefore neither means to abolish his approach, theory and politics, nor to completely re-invent them, nor to leave them unchanged. That capitalism is a historical and dialectical system means that it changes through crises in order to remain the same system of exploitation. To repeat Marx therefore means to sublate Marx's categories based on a dialectic of continuity and change. Whereas postmodernists have preached for decades that society has completely changed, orthodox social theorists claim that nothing at all has changed. Postmodernism overestimates change. The orthodoxy that nothing ever changes in contrast overestimates continuity.

Second, the contemporary capitalist age is profoundly ideological. To understand and change society, we therefore need to repeat Marx's ideology critique. Through consumer culture and neoliberalism, we have experienced the commodification of (almost) everything and the constant presence of ideologies that justify commodity logic in all realms of everyday life. Commodity fetishism as ideology immanent to capital itself has thereby become universal. Rising inequalities have resulted in the intensification and extension ideologies that distract attention from capitalist society as the underlying cause of social problems. The most evident form of political fetishism has in recent times been the rise of new political nationalisms.

Third, to repeat Marx today means to envision and struggle for alternatives to capitalism. Marx stresses that history is not pre-determined and that humans make their own history. Even in dark times, it is never too late. And it is especially in such times important to envision alternatives and think of - and work towards - ways to overcome the gap between what could be and what is. Capitalism is not the end of history. In order to humanise society, fundamental societal change is needed.

To repeat Marx means to renew, recast, revitalise, rethink, reconsider, and reinterpret Marx today.

\section{200 Years of Social Struggles for Alternatives to Capitalism}

The financial crisis of 2008 and the subsequent regimes of social, political and ideological austerity - accompanied by the rise of new nationalisms and authoritarian forms of capitalism - gave new momentum to critical analyses of contemporary capitalism that are not limited to academic debates, but are starting to penetrate the public arena and mainstream discourse. Current debates focus on the possibility to envision alternatives to rather than alternatives of capitalism. If we want to take the project of envisioning and realising an alternative to capitalism seriously, it becomes clear that we have to move beyond the mere critique of capitalism and have to interpret and put into praxis Marx's legacy for the relevance of realising alternatives today.

The implication is that we have to recognise that on the one side the functioning of 21 st-century capitalism is slightly different to the capitalism described by Karl Marx in Capital, and, on the other, that the capitalism we are living in today constitutes an evolution of 19th-century capitalism and, as such, the system reproduces itself fol- 
lowing the same dynamics of exploitation, accumulation, and commodification outlined by Marxian analyses. If we then turn our focus towards the alternatives, the main questions become: What would the alternative system (or systems) to capitalism look like? How can we realise alternatives? Answering this question is probably the main challenge for radical theorists today.

The historical trajectory of capitalism is crowded with attempts to establish alternative systems. The search for alternatives took an important turn in the Paris Commune in 1871 and passed through the revolutions and resistance movements that characterised the entire course of the twentieth century - in Russia, Germany, India, Ireland, Nicaragua, Spain, Italy, Indonesia, China, Cuba, the 1968 movement, the Zapatista movement in Mexico, the most recent Bolivarian revolution in Venezuela, and in the Rojava movement in Syria. History also reminds us that many of these revolutions have been and are repressed with violence, while others led to authoritarian, centralised and repressive regimes. A systematic attempt to establish a 'socialism of the twenty-first century' comes from Latin America and the various governments settled there in the last decade: Evo Morales in Bolivia, Luiz Inácio Lula da Silva in Brazil, Rafael Correa in Ecuador, Fernando Lugo in Paraguay, Hugo Chavez in Venezuela, or Tabaré Vázquez and José Mujica in Uruguay. The project of a socialism for the twenty-first century is characterised by the opposition to neoliberalism, a rejection of Soviet-style 'state socialism', and a deep focus on rethinking 'the good living' (in Spanish: buen vivir) in harmony with the nature. As defined by Michael A. Lebowitz (2016), "socialism for the twenty-first century is a revolutionary restoration - the return to Marx's understanding of socialism [...] [that] puts human development, the full development of human potential at the centre".

Nonetheless, former Brazilian president Lula's recent controversial sentence for corruption and money laundering and the popular uprisings in Venezuela against the government of current president Nicolás Maduro constitute a sign that the so-called 'pink-tide' Latin American project - that started with the election of Hugo Chavez in 1998 - is encountering both internal and external challenges and, as the Venezuelan case shows, has some contradictory and problematic contours. While there is a certain crisis of the Latin American left-wing project, in the United States and Europe, the rise of socialist politicians like Bernie Sanders and Jeremy Corbyn as a reaction to the politics of the neoliberal 'third way' and the financialisation of the economy indicates that also in these parts of the world socialism is a force to reckon with. Corbyn and Sanders are only the two most famous examples. In other European countries, political movements and parties are explicitly recalling in their programmes aspects of equality, solidarity, redistribution and social justice and are advocating policies like universal and unconditional basic income, free education, and the expansion of the provision of public services.

All of these political programmes share not only a critique of neoliberalism as the political paradigm that has dominated the last forty years, but most importantly the consciousness that we need to establish positive, progressive, democratic alternatives capable of overcoming capitalism. To foster this urgency, there is not just the need to overcome social inequalities, but also to avoid the planet's ecological catastrophe. Social and ecological justice are not mutually exclusive, but two essential and profoundly intertwined points of the contemporary radical Left's political agenda. During Marx's lifetime, the environmental crisis was not as severe and pressing as it has become today. In his critique, he described the rupture between humanity and the rest of nature caused by the modes of capitalist production that is now central to the writings of many Marxist and ecological thinkers and that has been termed the "met- 
abolic rift" (Foster 2000). Marx was an early radical thinker of environmental sustainability (Fuchs 2006), when he argued that "a whole society, a nation, or even all simultaneously existing societies taken together, are not the owners of the globe" and that humans have the responsibility to hand down the globe "to succeeding generations in an improved condition" (Marx 1894, 784).

Whether one believes that future society should be inspired by the principles of eco-socialism or by hyper-technological post-work ideas, the timelessness of Marxist thinking is evident throughout this special issue.

\section{The Contributions in this Special Issue}

This special issue celebration of Marx's bicentenary opens with a debate between David Harvey, Michael Hardt and Toni Negri on the relevance of Marx and how to critically theorise capitalism today: David Harvey in the article "Universal Alienation" argues that a theory of objective alienation along with an understanding of its subjective consequences is vital for progressive politics today. In the paper "The Powers of the Exploited and the Social Ontology of Praxis", Michael Hardt and Toni Negri discuss the extraction of value from the common and what forms of praxis are needed today. In "The Multiplicities within Capitalist Rule and the Articulation of Struggles", Hardt and Negri respond to David Harvey's article. They argue that Harvey's reading of Marx's notion of alienation as universal process is important. They also point out that they find the notions of formal and real subsumption best suited for pointing out the internal dynamics of capital and the relationship of capitalism, patriarchy and racism. David Harvey's final response to Hardt and Negri is titled "Universal Alienation and the Real Subsumption of Daily Life under Capital: A Response to Hardt and Negri'. He supports Hardt and Negri's theoretical move to extend Marx's categories of the formal and real subsumption of labour under capital to other aspects of society and stresses that it is important to discern what it is that is being subsumed into what and what the effects of subsumption are. Harvey points out the complementary character of the categories of universal alienation and the real subsumption of society under capital. A comment by Christian Fuchs concludes the Harvey/Hardt/Negri-debate. Its title is "Universal Alienation, Formal and Real Subsumption of Society under Capital, Ongoing Primitive Accumulation by Dispossession: Reflections on the Marx@200-Contributions by David Harvey and Michael Hardt/Toni Negri".

Silvia Federici's article "Marxism and Feminism" discusses aspects of feminism and gender in Marx's theory and argues for integrating the analyses of reproductive labour, slave labour, migrant labour, labour in the Global South and the unemployed in the critical analysis of capitalism and its division of labour.

Slavoj Žižek reflects in his contribution on the prospects of radical political and societal transformations today. His article "The Prospects of Radical Change Today" revisits the failures of Stalinism, poses the question of the revolutionary subject and democracy today by analysing the "interesting times" we live in today.

Erik Olin Wright's contribution "The Continuing Relevance of the Marxist Tradition for Transcending Capitalism" suggests that the Marxist tradition remains relevant today for understanding how capitalism impacts human flourishing, that alternatives are possible, capitalism is contradictory, and emancipation requires social struggles.

Lara Monticelli in her article "Embodying Alternatives to Capitalism in the 21st Century" highlights how, after the financial collapse of 2008, Marxist scholars have broadened their focus by including in their analyses on the potential subjects of 
emancipation, social movements and grassroots initiatives that are "interstitial". She claims that the time is ripe for establishing a theory of and for prefigurative social movements.

Christian Fuchs argues in "Karl Marx \& Communication @ 200: Towards a Marxian Theory of Communication" that Marx's works are an important foundation for critically theorising communication, which includes understanding the relationship of communication and materialism (communicative materialism), the role of the means of communication and communicative labour in capitalism, ideology as a form of fetishised communication and fetishism as ideological communication.

Peter Goodwin in the article "Where's the Working Class?" discusses the relevance of the notion of the working class in the works of Marx and Engels and the history of Marxism and situates the development of the concept of the working class in the context of political economic history. The contribution raises a number of questions about Marxism and the contemporary working class that any Marxist today needs to answer.

Friederike Beier's paper "Marxist Perspectives on the Global Enclosures of Social Reproduction" discusses the notion of social reproduction from a Marxistfeminist perspective. She relates the discussion to the notions of enclosure and primitive accumulation and points out how to critically make sense of the role of unpaid domestic and care labour today.

Wayne Hope in the article "Epochality, Global Capitalism and Ecology" discusses how Marxist theory can explain the interconnection of global capitalism, nature, the environmental crisis, financialisation, real time and communications. He updates the contemporary discussion of the Anthropocene from a Marxist theory perspective.

Todd Wolfson and Peter Funke's paper "The History of all Hitherto Existing Society": Class Struggle and the Current Wave of Resistance" analyses the relevance of Marx's notions of class and class struggles for understanding contemporary social movements. They point out the relevance of interrelating objective and subjective dimensions of class - class position and class consciousness/class struggles.

Joss Hands in the contribution "Marx, Materialism and the Brain: Determination in the Last Instance?" discusses how to make sense of brain activities and consciousness from a Marxian and materialist perspective. In this context, particular attention is given to the notions of the General Intellect, determination, the base/superstructure problem, and aspects of the digital.

Peter McLaren and Petar Jandrić's article "Karl Marx and Liberation Theology: Dialectical Materialism and Christian Spirituality in, against, and beyond Contemporary Capitalism" pinpoints the convergences and discrepancies between liberation theology and the works of Karl Marx. The article contributes to the question of how to make sense of the relationship of Marxism and theology today.

Ingo Schmidt's paper "Reading Capital after 20th-Century Orthodoxies and Revisions" discusses different readings of Marx's Capital, which shows a plurality of approaches for understanding to continued relevance of Karl Marx and his opus magnum Capital in the 21st century. The article argues for a synthetic approach that avoids both orthodoxy and revisionism.

Christian Fuchs reviews Sven-Eric Liedman's Marx-biography "A World to Win: The Life and Works of Karl Marx" that was published shortly before Marx' bicentenary.

Bahar Kayıhan in "An Analysis of Marx's Legacy in the Field of Communication Studies" analyses the role of Marxist studies in the academic field of communi- 
cation studies and focuses on topics such as digital capitalism, digital labour, and the digital commodity. The contribution shows the relevance of Marx in the 21st century for understanding the latest developments in communications.

Joff P.N. Bradley and Alex Taek-Gwang Lee in their article "On the LumpenPrecariat-To-Come" discuss Marx's notion of the lumpenproletariat. They argue that this concept has relevance for the critical analysis of capitalism today and underpin the update of this notion as lumpen-precariat by insights into the political economies of Japan and South Korea.

Paul O'Connell's contribution “Law, Marxism and Method" points out elements from Marx's works and the Marxist theory tradition that help us to critically understand the nature and role of law, the state and rights in contemporary capitalism law, state and rights. The article in this context stresses the relevance of dialectical analysis, the historical character of capitalism, and the role of class.

Chihab El Khachab's “Two Questions to Marxist Anthropology" discusses the relationship of Marxist theory and anthropology. It argues that the integration of Marxism and anthropology needs to give special attention to two questions: 1) How can micro- and macro-social scales in social scientific analysis be integrated? 2) How can we distinguish between conventional ideas and ideologies through which humans guide their lives under capitalism?

Franklin Dmitryev and Eugene Gogol's paper “Marx's Philosophy of Revolution in Permanence: Its Significance for Our Time" analyses the relevance of Marx's philosophy of revolution in the 21st century. They document aspects of Marx's writings on revolution and, with the help of special reference to Raya Dunayevskaya's Marxist humanist approach, point out the significance of his humanism and dialectical analysis for liberation struggles today.

Bryant William Sculos' article “Minding the Gap: Marxian Reflections on the Transition from Capitalism to Postcapitalism" discusses the relationship between capitalism and postcapitalism by analysing some of Marx's writings on this issue. He argues that especially Marx's dialectics and his conceptualisation of subjectivity are of special relevance for informing 21st century political praxis.

Leila Salim Leal's contribution "Ideology, Alienation and Reification: Concepts for a Radical Theory of Communication in Contemporary Capitalism" points out the continued relevance of the Marxist notions of ideology, alienation and reification for critically understanding the role of communication in 21 st-century capitalism. She argues that social movements need to avoid an individualist understanding of communications in protests.

Paul Reynolds' “Sexual Capitalism: Marxist Reflections on Sexual Politics, Culture and Economy in the 21st Century" focuses on the relevance of Marxian analysis for the critique of sexuality and sexual capitalism. The article shows that Marxism has become a central and important ground for exploring sexuality under capitalism in its objectifying, commodifying, alienating and exploitative forms.

Ben Whitham's contribution "Thinking the 'Culture Wars' and the Present Political Crisis With the Young Marx (and Friends)" focuses on the writings of the young Marx as inspiration for the critique of contemporary culture wars and political crises in the context of Brexit, Trump, neoliberalism, patriarchy, new nationalisms and racism.

Christian Fuchs' contribution “Marx's Centenary (1918) in the Light of the Media and Socialist Thought" takes a historical view on Marx's anniversary: it analyses how Marx's centenary (5 May 1918) was reflected in the media and socialist thought. 
We conclude the special issue with the English translation of Rosa Luxemburg's text "Karl Marx" that she wrote on the occasion of the 30th commemoration day of Marx's death. It deals with bourgeois criticisms of Marx, the working class, materialism, praxis, and revolutionary Realpolitik. Christian Fuchs' postface 'Karl Marx and Rosa Luxemburg" asks how we can make sense of Rosa Luxemburg's reading of Marx in 2018, as her text is an occasion for thinking about what it means to repeat Marx today.

Taken together, the contributions in this special issue show that Marx's theory and politics remain key inspirations for understanding exploitation and domination in 21 st-century society and for struggles that aim at overcoming these phenomena and establishing a just and fair society. These engagements with Marx's works on the occasion of his bicentenary make evident that Marxian theory is a true form of transdisciplinary thought and activity that has inspired the critical analysis of all aspects of contemporary society, including capital(ism), class, alienation, patriarchy, racism, sexism, nationalism, ideology, communication, praxis and social struggles, the working class, social movements, revolution, post-capitalism, social reproduction, enclosures, the commons, the state, the human being, nature and the ecological crisis, culture, imperialism, warfare, etc.

"Criticism has torn up the imaginary flowers from the chain not so that man shall wear the unadorned, bleak chain but so that he will shake off the chain and pluck the living flower. [...] In the struggle against those [inhumane] conditions criticism is no passion of the head, it is the head of passion". --- Marx (1844, 176-177)

Critique is the struggle for beauty in the world in order to make it a world for all. We need to repeat Marx today!

\section{References}

Eagleton, Terry. 2011. Why Marx Was Right. New Haven, CT: Yale University Press.

Foster, John Bellamy. 2000. Marx's Ecology. Materialism and Nature. New York: Monthly Review Press.

Fuchs, Christian. 2018. Digital Demagogue: Authoritarian Capitalism in the Age of Trump and Twitter. London: Pluto.

Fuchs, Christian. 2006. The Dialectic of the Nature-Society-System. tripleC 4 (1): 1-39.

Lebowitz, Michael A. 2016. What Is Socialism for the Twenty-First Century? Monthly Review

68 (5), https://monthlyreview.org/2016/10/01/what-is-socialism-for-the-twenty-first-century/

Marx, Karl. 1894. Capital Volume III. London: Penguin.

Marx, Karl. 1844. Contribution to the Critique of Hegel's Philosphy of Law. Introduction. In Marx \& Engels Collected Works Volume 3, 175-187. London: Lawrence \& Wishart.

\section{About the Authors/Editors}

Christian Fuchs is a critical theorist of communication and society. He is co-editor of the journal tripleC: Communication, Capitalism \& Critique and a professor at the University of Westminster. @fuchschristian http://fuchs.uti.at

Lara Monticelli is an independent researcher and prospective Assistant Professor and Marie Skłodowska-Curie fellow at the Department of Management, Politics and Philosophy at Copenhagen Business School (from September 2018 onwards). She is the co-founder of the newly established research network "Alternatives to Capitalism" within the Society for the Advancement of Socio-Economics (SASE). 